\title{
Rapid Detection of Lily mottle virus and Arabis mosaic virus Infecting Lily (Lilium spp.) Using Reverse Transcription Loop-Mediated Isothermal Amplification
}

\author{
Yubao Zhang (D), Yajun Wang, Zhongkui Xie*, Ruoyu Wang, Zhihong Guo, and Yuhui He \\ Northwest Institute of Eco-Environment and Resources, Chinese Academy of Sciences, Lanzhou 730000, China \\ (Received on April 16, 2019; Revised on November 28, 2019; Accepted on February 3, 2020)
}

The Lily mottle virus (LMoV) impedes the growth and quality of lily crops in Lanzhou, China. Recently Arabis mosaic virus (ArMV) has been detected in LMoVinfected plants in this region, causing plant stunting as well as severe foliar symptoms, and likely posing a threat to lily production. Consequently, there is a need to develop simple, sensitive, and reliable detection methods for these two viruses to prevent them from spreading. Reverse transcription (RT) loop-mediated isothermal amplification (LAMP) assays have been developed to detect $\mathrm{LMoV}$ and ArMV using two primer pairs that match six conserved sequences of $\mathrm{LMoV}$ and ArMV coat proteins, respectively. RT-LAMP assay results were visually assessed in reaction tubes using green fluorescence and gel electrophoresis. Our assays successfully detected both LMoV and ArMV in lily plants without the occurrence of viral cross-reactivity from other lily viruses. Optimal conditions for LAMP reactions were $65^{\circ} \mathrm{C}$ and $60^{\circ} \mathrm{C}$ for $60 \mathrm{~min}$ for $\mathrm{LMoV}$ and ArMV, respectively. Detection sensitivity for both RT-LAMP assays was a hundredfold greater than that of our comparative RT-polymerase chain reaction assays. We have also found this relatively rapid, target specific and sensitive method can also be used for sam-

\footnotetext{
*Corresponding author.

Phone) +86-931-4967204, FAX) +86-931-8273894

E-mail)wxhcas@1zb.ac.cn,zyubao@yahoo.com

ORCID

Yubao Zhang

https://orcid.org/0000-0001-8438-0810

(cc) This is an Open Access article distributed under the terms of the Creative Commons Attribution Non-Commercial License (http:// creativecommons.org/licenses/by-nc/4.0) which permits unrestricted noncommercial use, distribution, and reproduction in any medium, provided the original work is properly cited.
}

Articles can be freely viewed online at www.ppjonline.org. ples collected in the field and may be especially useful in regions with limited or no laboratory facilities.

Keywords : Arabis mosaic virus, lily, Lily mottle virus, RTLAMP amplification, RT-PCR

Handling Editor : Ho-Jong Ju

In Lanzhou, China, lilies (Lilium spp.) are an important economic crop of the floricultural industry. Also of economic importance are Lanzhou lily (Lilium davidii var. unicolor) bulbs, grown for their edible and medicinal properties (Zhang et al., 2018). Given that most lilies are grown by vegetative propagation, bulbs may be infected with viruses and consequently transmit from one generation to the next. Moreover, there are more than 10 different viruses that cause lily crops of quality and quantity damage throughout the world (Wang et al., 2010). The Lily mottle virus (LMoV; genus Potyvirus, family Potyviridae), being widespread throughout China, is a non-enveloped, rodshaped flexuous virus with a width of 11 to $15 \mathrm{~nm}$ and a length of 680 to $900 \mathrm{~nm}$ (Zhang et al., 2017). LMoV infection is characterized by deformity, curling, mottling and necrotic of leaves along with necrotic spotting and deformation of flowers (Zhang et al., 2015b). LMoVinfected plants co-infected with Lily symptomless virus (LSV) may also show plant stunting as well as more severe foliar symptoms (Asjes, 2000; Zhao et al., 2018). LMoV can be transmitted through vegetative propagation, mechanically from plant to plant or by aphids (Asjes, 2000; Derks et al., 1994; Zhang et al., 2018).

In 2017, Arabis mosaic virus (ArMV; genus Nepovirus, family Comoviridae) was detected in LMoV-infected plants in a lily field within the Gaolan Research Station (Gaolan County, Lanzhou, Gansu Province, China; 


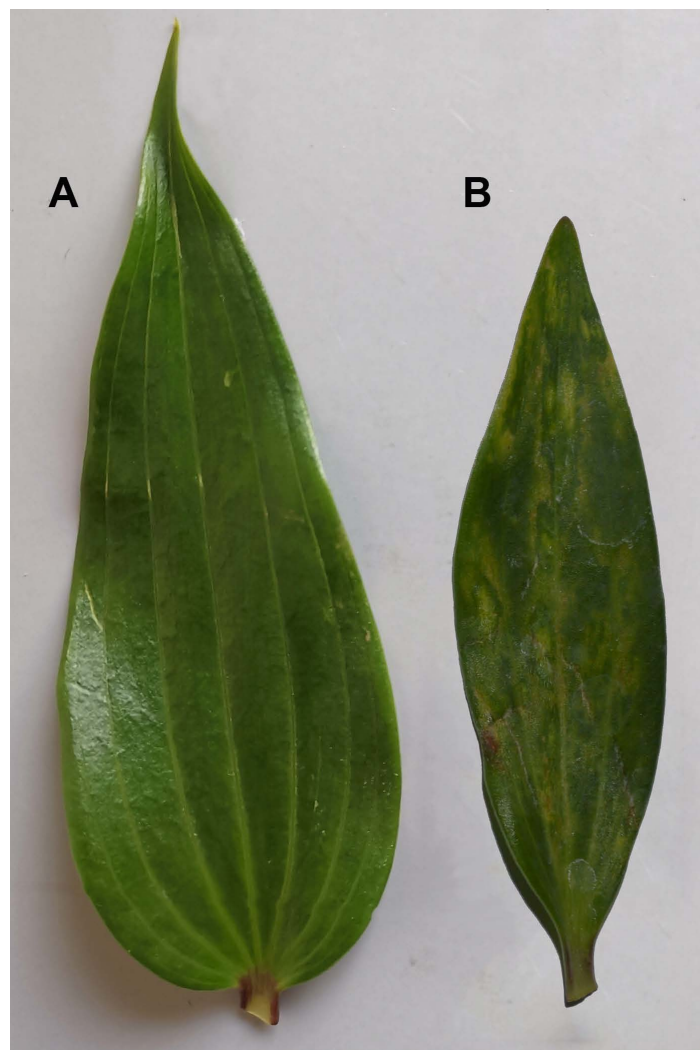

Fig. 1. Healthy lily leaf (A) and leaf exhibiting symptoms caused by mixed infections with Lily mottle virus (LMoV) and Arabis mosaic virus (ArMV) (B).

3613"N, 10347"E; Field Station, Northwest Institute of Eco-Environment and Resources, Chinese Academy of Sciences, Lanzhou, Gansu Province, China) by a lily research group from the Northwest Institute of Eco-Environment and Resources (NIEER), Chinese Academy of Sciences (CAS) (unpublished report). ArMV is isometric in shape and approximately $30 \mathrm{~nm}$ in diameter. In China, ArMV is a second-class quarantinable plant virus. Lilies infected only with ArMV show symptoms of leaf mosaic, chlorosis, stunting, crinkling, and necrosis (Zheng et al., 2013). Similarly, ArMV and LMoV infected plants may also show a sign of plant stunting as well as severe foliar symptoms, including leaf mosaic with necrotic leaf spotting (Fig. 1). ArMV is transmitted by nematodes such as Xiphinema diversicaudatum and Longidorus macrosoma (Brunt et al., 1996). Like LMoV, ArMV can be transmitted mechanically from plant to plant (EFSA Panel on Plant Health, 2013); or through lily bulb vegetative propagation (Zhang et al., 2015b).

Virus management is dependent upon an accurate detection procedure which is convenient, reproducible and scalable for a wide range of samples (Viswanathan et al.,
2013). There are a number of approaches used in identifying LMoV and ArMV in lilies, including enzyme-linked immunosorbent assay (ELISA), reverse transcriptionpolymerase chain reaction (RT-PCR) and immunocapture (IC)-RT-PCR assays. While ELISA has been used to detect both LMoV and ArMV, false negative results and low sensitivity are a problem when dealing with lily bulb samples and in the detection of ArMV in hops (Adams et al., 1987; Sharma et al., 2005). RT-PCR has also been widely used in the detection of LMoV and ArMV; however, polysaccharide, polyphenol as well as other inhibitors in lily bulbs present in RNA extracts have been found to reduce RTPCR sensitivity (Kulshrestha et al., 2005; Kwon et al., 2013; Zhang et al., 2015b). On the one hand, the IC-RTPCR technique is not required for RNA isolation, reduces problems associated with PCR inhibitors and provides a more rapid and a less costly approach to preparing templates for amplification (Gambley et al., 2009). On the other hand, IC-RT-PCR sensitivity is likely to be inadequate in detecting low virus concentrations in lilies (Zhang et al., 2017; Zheng et al., 2013).

The RT-loop-mediated isothermal amplification (RTLAMP) method is a rapid, specific, and sensitive diagnostic technique of relatively low cost that has been applied in the detection of a variety of plant viruses, including the Barley yellow dwarf virus (BYDV) (Zhao et al., 2010), the Piper yellow mottle virus (PYMoV), the Cucumber mosaic virus (CMV) (Bhat et al., 2013), the Turnip mosaic virus (TuMV) (Zhao et al., 2014), the Sugarcane mosaic virus (SCMV), the Sorghum mosaic virus (SrMV) (Keizerweerd et al., 2015) and the LSV (He et al., 2016). In this method, LAMP amplification reactions are typically conducted at a constant temperature between $60-70^{\circ} \mathrm{C}$ for approximately $1 \mathrm{~h}$ in a water bath or heating block. Moreover, amplicons can be readily visualized by adding SYBR Green I to the reaction mixture (Mengao et al., 2016; Parida et al., 2008). In this study, we have developed and optimized a simple and reliable RT-LAMP method for the rapid and accurate detection of $\mathrm{LMoV}$ and ArMV in lily plants. Results from our RT-LAMP assays were then compared to our established RT-PCR assays.

\section{Materials and Methods}

Plant materials. Naturally infected oriental hybrid lily (Lilium oriental cv. Sorbonne) plants that exhibited typical symptoms of plant dwarfing, chlorotic (yellowing) leaf spotting or striping were collected from fields within the Gaolan Research Station. RT-PCR was used to test leaves removed from near the flower bud as described by Zhang 
Table 1. Sequences of primers used for RT-LAMP and RT-PCR of Lily mottle virus (LMoV) and Arabis mosaic virus (ArMV)

\begin{tabular}{|c|c|c|c|}
\hline Primer names & Type & Position $^{\mathrm{a}}$ & Sequence $\left(5^{\prime}-3^{\prime}\right)$ \\
\hline LMoV-F3 & Forward outer primer for RT-LAMP & $9,024-9,041$ & AATGGCGTGTGGCTCATG \\
\hline LMoV-B3 & Backward outer primer for RT-LAMP & $9,193-9,212$ & GGTGAGATTTCGCTGAAGGC \\
\hline LMoV-FIP & $\begin{array}{l}\text { Forward inner primer (F1c-F2) for } \\
\text { RT-LAMP }\end{array}$ & $\begin{array}{l}\mathrm{F} 1_{\mathrm{C}}: 9,083-9,104 \\
\mathrm{~F} 2: 9,043-9,062\end{array}$ & $\begin{array}{l}\text { CGTCGGTTTTGCGTGTTCAAGTTGGACGGA- } \\
\text { GATCAGCAAGTT }\end{array}$ \\
\hline LMoV-BIP & $\begin{array}{l}\text { Backward inner primer (B1c-B2) for } \\
\text { RT-LAMP }\end{array}$ & $\begin{array}{l}\mathrm{B} 1_{\mathrm{C}}: 9,120-9,141 \\
\mathrm{~B} 2: 9,173-9,192\end{array}$ & $\begin{array}{l}\text { GCGCATTTCTCAAACCTCGCTGCGTACCTAG- } \\
\text { GCATGTACGGT }\end{array}$ \\
\hline LMoV-F & For RT-PCR & $9,005-9,023$ & TGGCACCTCACCAAATGTA \\
\hline LMoV-B & For RT-PCR & $9,399-9,419$ & CATCATCTGCTGTATGCCTCT \\
\hline ArMV-F3 & Forward outer primer for RT-LAMP & $2,950-2,969$ & CGAGTGGAGAAACTGCTAAG \\
\hline ArMV-B3 & Backward outer primer for RT-LAMP & $3,162-3,181$ & CCATGACAAGCTATCATGTG \\
\hline ArMV-FIP & $\begin{array}{l}\text { Forward inner primer (F1c-F2) for } \\
\text { RT-LAMP }\end{array}$ & $\begin{array}{l}\mathrm{F} 1_{\mathrm{C}}: 3,041-3,064 \\
\mathrm{~F} 2: 2,984-3,005\end{array}$ & $\begin{array}{l}\text { GCAGAAAAGTCCACCCAAAGAAAAGCAAATT- } \\
\text { GACGAAATTGCATTA }\end{array}$ \\
\hline ArMV-BIP & $\begin{array}{l}\text { Backward inner primer (B1c-B2) for } \\
\text { RT-LAMP }\end{array}$ & $\begin{array}{l}\mathrm{B} 1_{\mathrm{C}}: 3,078-3,102 \\
\mathrm{~B} 2: 3,138-3,155\end{array}$ & $\begin{array}{l}\text { ACAGAAGAGTATGTAATAGGGTCGAAGGAT- } \\
\text { TATCTCCCAGGGC }\end{array}$ \\
\hline ArMV-F & For RT-PCR & $2,241-2,262$ & ACTACTGCTAGTCCTGCGTATA \\
\hline ArMV-B & For RT-PCR & $2,673-2,690$ & ATAGAACCGTAGCCACCG \\
\hline
\end{tabular}

RT-LAMP, reverse transcription loop-mediated isothermal amplification; RT-PCR, reverse transcription polymerase chain reaction. ${ }^{a}$ Gene position based on the nucleotide sequence of the LMoV and ArMV coat proteins (CP) (accession nos. AJ564636 and AB279740.2) respectively.

et al. (2015a) to confirm their respective virus infections. Leaves from a single plant specimen that tested positive for $\mathrm{LMoV}$, ArMV, LSV, or CMV, serving as a source of these viruses, were selected and stored at $-70^{\circ} \mathrm{C}$ for use in our experiments.

RT-LAMP primer design. The conserved regions of coat proteins $(\mathrm{CP})$ were used as the basis for the design of RTLAMP primers for LMoV and ArMV detection by establishing sequence alignments (multiple sequence alignment) of LMoV and ArMV CP gene sequences from lily hosts available from GenBank (Zhang et al., 2015b; Zheng et al., 2013). Primer design was conducted using PrimerExplorer V5 software, from Eiken Chemical Co., Ltd. (Tokyo, Japan) using the default settings. Two LAMP external primers (F3 and B3) and two internal primers (FIP [F1c+F2] and $\mathrm{BIP}[\mathrm{B} 1 \mathrm{c}+\mathrm{F} 2])$ were designed, which are capable of detecting six LMoV and ArMV CP gene sequences, respectively (sequences shown in Table 1).

RNA extraction. Total RNA was extracted from lily leaves using the RNAprep Pure Kit (For Plant) from Tiangen Biotech (Beijing) Co., Ltd. (Beijing, China). A lily leaf sample (0.05-0.1 g) was ground in liquid nitrogen, after which $450 \mathrm{ml}$ of lysate was added. Following this, further extraction steps were conducted as per the manufacturer's instructions. The final elution step was conducted using 50 $\mu \mathrm{l}$ of RNAse-free $\mathrm{H}_{2} \mathrm{O}$. The RNA concentration was mea- sured using the NanoDrop ND-1000 Spectrophotometer (NanoDrop Technologies, Wilmington, DE, USA) and adjusted for RT-LAMP and RT-PCR analyses.

RT-LAMP and its optimization. The PrimeScript RT Reagent Kit (Takara Biotech, Dalian, China) was used for RT, and then the first strand of viral cDNAs was synthesized according to the manufacturer's instructions. LAMP reactions were conducted in $12.5 \mu \mathrm{l}$ reaction volumes that contained $0.5 \mu \mathrm{lDNA}$ products $(50 \mathrm{ng}), 1.25$ $\mu \mathrm{l}$ of a $10 \times$ ThermoPol buffer (New England BioLabs, Ipswich, MA, USA), $0.75 \mu \mathrm{l}$ of $100 \mathrm{mM} \mathrm{MgSO}_{4}, 1.75 \mu \mathrm{l}$ of $10 \mathrm{mM}$ dNTPs, $0.25 \mu \mathrm{l}$ each of the external primers F3 and B3 $(10 \mu \mathrm{M}), 2.0 \mu \mathrm{l}$ each of the internal primers FIP and BIP $(10 \mu \mathrm{M}), 0.5 \mu \mathrm{l}$ of Bst DNA polymerase ( $8 \mathrm{U} / \mu \mathrm{l}$; New England Bio Labs), and distilled $\mathrm{H}_{2} \mathrm{O}$ to a final volume of $12.5 \mu \mathrm{l}$.

We then determined the optimum incubation temperature and duration time of each primer set of $\mathrm{LMoV}$ and ArMV for the RT-LAMP assays. To determine the optimum temperature, the reaction was conducted for $100 \mathrm{~min}$ at seven different temperatures: $56,58,60,62,65,68$, and $70^{\circ} \mathrm{C}$, followed by $80^{\circ} \mathrm{C}$ for $10 \mathrm{~min}$ in a thermal cycler (Bio-Rad, Hercules, CA, USA). To determine the optimum incubation duration (time), the reaction was conducted at $65^{\circ} \mathrm{C}$ and $60^{\circ} \mathrm{C}$ during five different time periods $(20,40,60,80$, and $100 \mathrm{~min}$ ) followed by $80^{\circ} \mathrm{C}$ for $10 \mathrm{~min}$ for $\mathrm{LMoV}$ and ArMV, respectively. 
RT-LAMP amplification products $(5 \mu \mathrm{l})$ were analyzed and evaluated by direct visual inspection of the reaction tube after the addition of SYBR Green I (1:1000 TE, v/v, Invitrogen, Carlsbad, CA, USA). In addition, RT-LAMP amplification products $(5 \mu \mathrm{l})$ were routinely detected with agarose gel electrophoresis (2.0\% agarose, TAE).

RT-PCR. The primer pair LMoV-F and LMoV-R (or ArMV-F and ArMV-R) was designed based on the conserved region of the $\mathrm{LMoV}$ or ArMV CP and was used for RT-PCR analysis, respectively (sequences shown in Table 1). As described above, total RNA was extracted from plants that tested positive for LMoV or ArMV using the RNAprep Pure Kit (For Plant). Subsequently, RT was performed to synthesize the first strand of cDNA according to the protocol described above. An optimum assay for PCR was conducted in $12.5 \mu$ reaction volumes containing 1.0 $\mu \mathrm{l}$ of cDNA products, $1.25 \mu \mathrm{l}$ of a 10 PCR buffer $(100 \mathrm{mM}$ Tris- $\mathrm{HCl}$ [pH 8.3], $\left.500 \mathrm{mM} \mathrm{KCl}, 15 \mathrm{mM} \mathrm{MgCl}_{2}\right), 2 \mu \mathrm{l}$ of a dNTP mixture (2.5 mM), $0.3 \mathrm{U}$ of Taq polymerase (TaKaRa Ex Taq, Takara Biotech) and $0.1 \mu \mathrm{M}$ of each LMoV-F and LMoV-R or ArMV-F and ArMV-R primers (Table 1). The PCR amplification consisted of 35 cycles at $94^{\circ} \mathrm{C}$ for 30 $\mathrm{s}, 59^{\circ} \mathrm{C}$ for $45 \mathrm{~s}$ and $72^{\circ} \mathrm{C}$ for $1 \mathrm{~min}$. Electrophoresis was used to check $5.0 \mu \mathrm{l}$ volumes of the PCR products on a $2.0 \%$ agarose gel and was confirmed to be the expected sizes (i.e., 395 and $449 \mathrm{bp}$ for LMoV and ArMV, respectively).

Analysis of RT-LAMP specificity. Total RNA extracts from lily leaves infected with LSV, CMV, LMoV, and ArMV were used to evaluate the cross-reactivity of the RTLAMP assay. Water and healthy lily leaves were used as the blank and negative controls, respectively.

Comparison between RT-LAMP and RT-PCR sensitivity. To compare the sensitivity of RT-LAMP to RT-PCR, total RNA $(100 \mathrm{ng} / \mu \mathrm{l})$ from lily leaves infected with $\mathrm{LMoV}$ or ArMV were used for both RT reactions. The synthesized cDNA products were serially diluted 10 -fold from $10^{-1}$ to $10^{-11}$ using initial cDNA. The serial dilutions were subjected to LAMP and PCR according to the aforementioned method.

Evaluation of RT-LAMP using field-collected samples. To validate the RT-LAMP assay, 10 Lanzhou lily and 10 oriental hybrid lily leaf samples were collected from the field within the Gaolan Research Station and were extracted as discussed above and tested for LMoV and ArMV using RT-LAMP. Amplification products $(5 \mu \mathrm{l})$ were detected using agarose gel electrophoresis $(2.0 \%$ agarose,
TAE) and by direct visual examination using SYBR Green I. As a comparison, each leaf sample was also tested using RT-PCR according to the aforementioned method.

\section{Results}

Optimization of RT-LAMP reactions. The optimum temperatures for the detection of LMoV and ArMV using RTLAMP were confirmed by means of 100 min RT-LAMP reactions at seven different temperatures, $56^{\circ} \mathrm{C}$ and $70^{\circ} \mathrm{C}$. For LMoV detection typical ladder-like patterns were observed using agarose gel electrophoresis at 65,68 , and $70^{\circ} \mathrm{C}$; however, no amplification was seen at $56,58,60$, and $62^{\circ} \mathrm{C}$ (Fig. 2A). For ArMV detection typical ladderlike patterns were clearly observed using agarose gel electrophoresis at $60,62,65,68$, and $70^{\circ} \mathrm{C}$; however, ladderlike patterns were only weakly observed using agarose gel electrophoresis at $58^{\circ} \mathrm{C}$. No amplification was observed at $56^{\circ} \mathrm{C}$ (Fig. 2B).

To determine the minimum reaction time for $\mathrm{LMoV}$ and ArMV detection, RT-LAMP was conducted at $65^{\circ} \mathrm{C}$ and $60^{\circ} \mathrm{C}$ for $20,40,60,80$, and $100 \mathrm{~min}$ for $\mathrm{LMoV}$ and ArMV, respectively. Typical ladder-like patterns were clearly observed at 60, 80, and $100 \mathrm{~min}$; however, no amplification was observed at 20 and $40 \mathrm{~min}$ in either case (Fig.

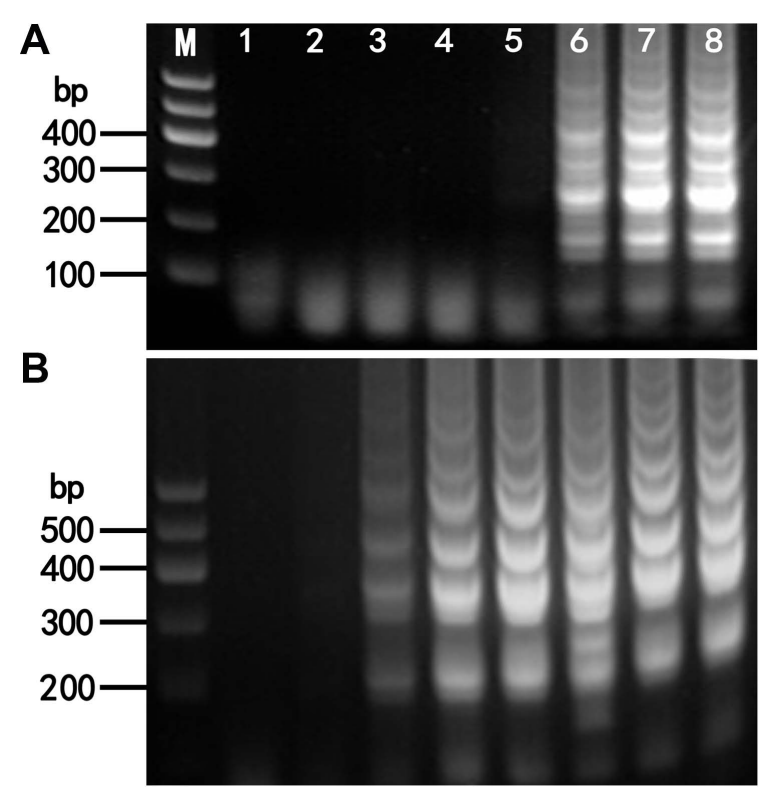

Fig. 2. Agarose gel electrophoresis showing the effect of different amplification temperatures on the detection of Lily mottle virus (LMoV) (A) and Arabis mosaic virus (ArMV) (B) by reverse transcription loop-mediated isothermal amplification. Lane $\mathrm{M}$, DL600 marker; lane 1, negative control; lanes 2-8, 56, 58, 60, 62, 65,68 , and $70^{\circ} \mathrm{C}$. 


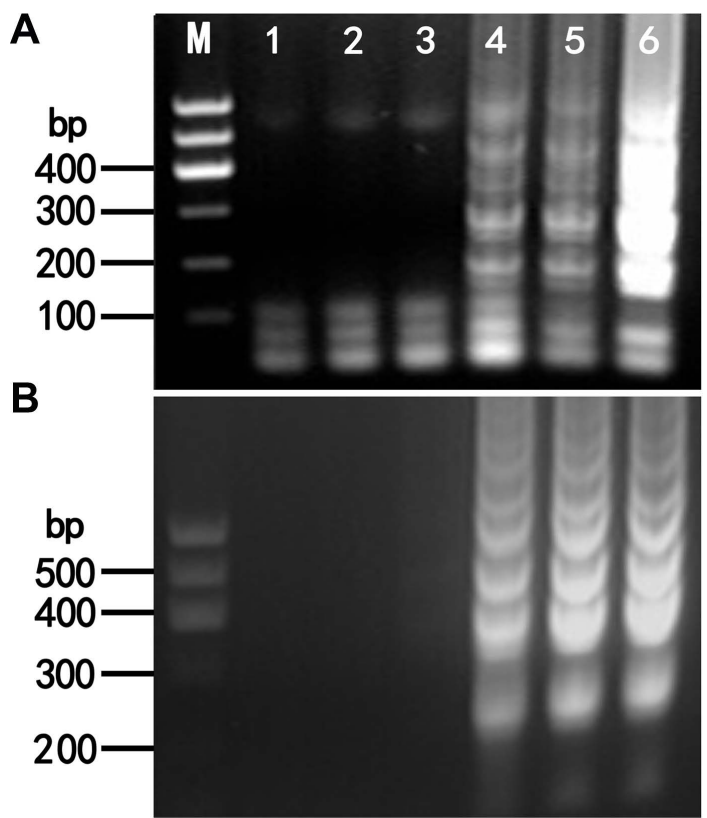

Fig. 3. Agarose gel electrophoresis showing the effect of different reaction durations on the detection of Lily mottle virus (LMoV) (A) and Arabis mosaic virus (ArMV) (B) by reverse transcription loop-mediated isothermal amplification. Lane M, DL600 marker; lane 1, negative control; lanes 2-6, 20, 40, 60, 80, and $100 \mathrm{~min}$.

3). Consequently, subsequent RT-LAMP analyses were conducted at $65^{\circ} \mathrm{C}$ and $60^{\circ} \mathrm{C}$ for $60 \mathrm{~min}$ for $\mathrm{LMoV}$ and ArMV, in our experiment.

Specificity of the RT-LAMP assay for LMoV and ArMV. To determine the specificity of RT-LAMP assays, we tested them using RNA extracts from lily leaves infected with LSV, CMV, LMoV, and ArMV. Following the application of RT-LAMP, only products of LMoV-infected samples exhibited a typical ladder-like pattern using agarose gel electrophoresis. No bands were observed in samples infected with LSV, CMV, or ArMV (Fig. 4A, upper). Similarly, only the products of ArMV-infected samples exhibited a typical ladder-like pattern with no bands observed in samples infected with LSV, CMV or LMoV (Fig. 4B, upper).

The reaction products of RT-LAMP were further confirmed by visualization through direct observation using green fluorescence after adding SYBR Green I. Only the products of $\mathrm{LMoV}$ and ArMV-infected samples exhibited a green fluorescence and were consequently visualized after adding SYBR Green I (Fig. 4A, lower and 4B, lower).

Sensitivity of RT-LAMP vs. RT-PCR. To compare sensitivities between RT-LAMP and RT-PCR, we used tenfold serial dilutions of initial cDNA products synthesized from RT as templates. The detection limits for $\mathrm{LMoV}$ were determined to be $10^{-10}$ using RT-LAMP (Fig. 5A, upper) and $10^{-8}$ using RT-PCR (Fig. 6A). The detection limits for ArMV were determined to be $10^{-8}$ using RT-LAMP (Fig. 5B, upper) and $10^{-6}$ using RT-PCR (Fig. 6B). Thus, the sensitivity of IC-RT-LAMP appeared to be greater by a factor of 100 compared with the sensitivity of RT-PCR for the detection of LMoV and ArMV. The reaction products of RT-LAMP were also directly observed using SYBR Green I fluorescence. Both methods yielded similar detection limit values for both viruses (Fig. 5A, lower and 5B,
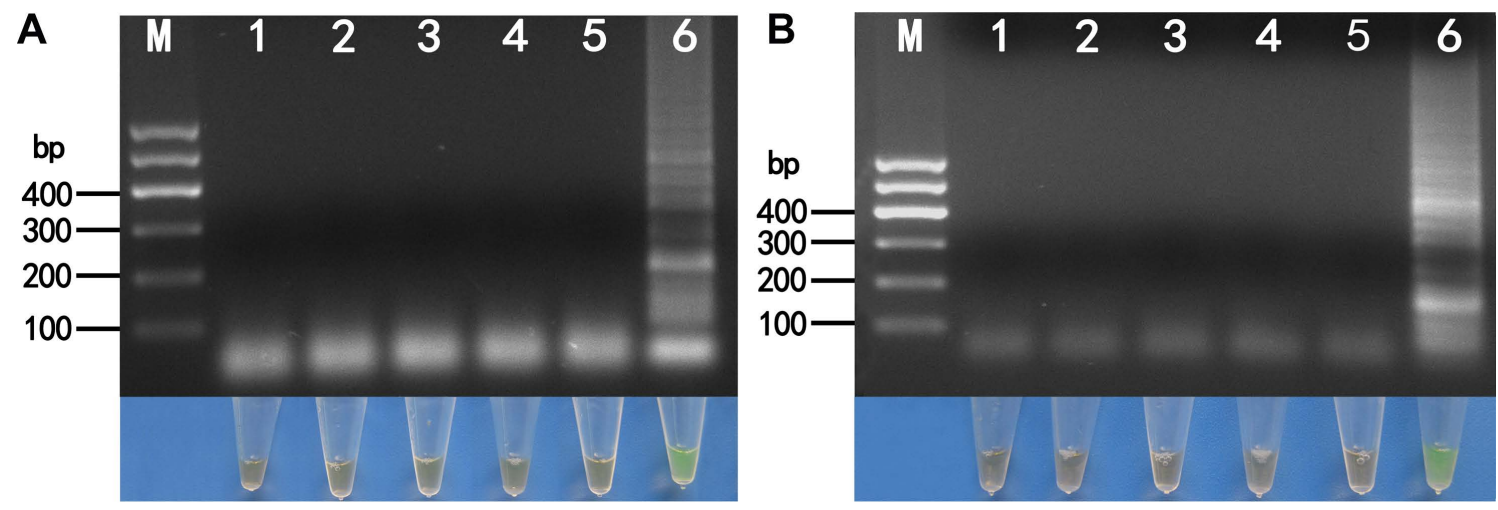

Fig. 4. Specificity of reverse transcription (RT) loop-mediated isothermal amplification (LAMP) for Lily mottle virus (LMoV) (A) and Arabis mosaic virus (ArMV) (B). Amplified products from RT-LAMP were visualized by agarose gel electrophoresis (upper) and by the naked eye with the addition SYBR Green I (lower). (A) LMoV. Lane M, DL600 marker; lane 1, negative control; lane 2, healthy lily; lane 3, Lily symptomless virus (LSV)-infected lily; lane 4, Cucumber mosaic virus (CMV)-infected lily; lane 5, ArMV-infected lily; lane 6, LMoV-infected lily. (B) ArMV. Lane M, DL600 marker; lane 1, negative control; lane 2, healthy lily; lane 3, LSV-infected lily; lane 4, CMV-infected lily; lane 5, LMoV-infected lily; lane 6, ArMV-infected lily. 

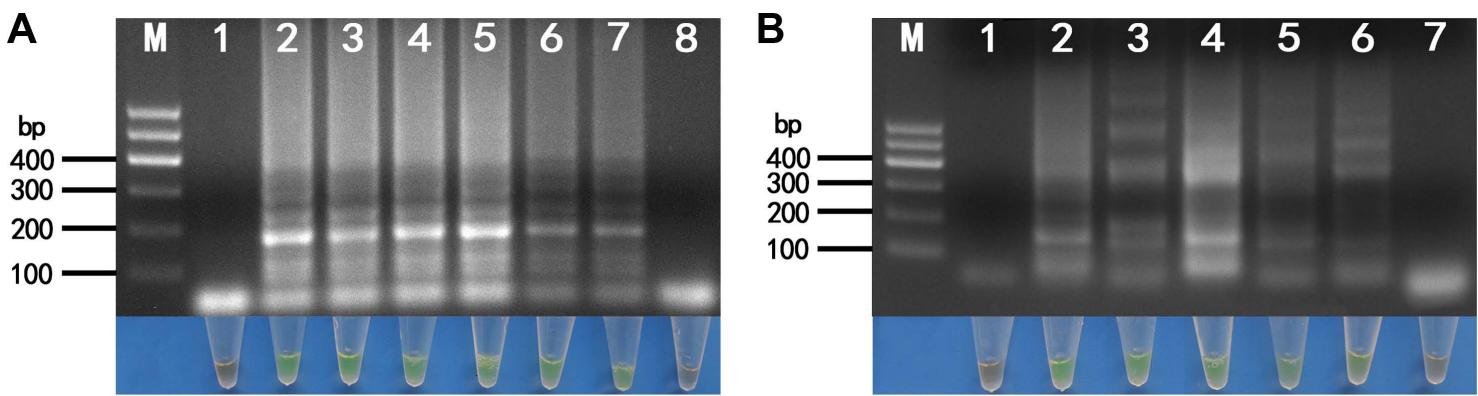

Fig. 5. Sensitivity of reverse transcription (RT) loop-mediated isothermal amplification (LAMP) for Lily mottle virus (LMoV) (A) and Arabis mosaic virus (ArMV) (B). cDNA products were synthesized using total RNA extracted from lily leaves that were each infected with LMoV or ArMV, which were respectively diluted 10-fold and assayed by LAMP. Amplified products from RT-LAMP were visualized by agarose gel electrophoresis (upper) and by the naked eye with the addition SYBR Green I (lower). (A) LMoV. Lane M, DL600 marker; lane 1 , negative control; lane $2,10^{-1}$; lane $3,10^{-3}$; lane $4,10^{-5}$; lane $5,10^{-7}$; lane $6,10^{-9}$; lane $7,10^{-10}$; lane $8,10^{-11}$. (B) ArMV. Lane M, DL600 marker; lane 1, negative control; lane $2,10^{-1}$; lane $3,10^{-3}$; lane $4,10^{-5}$; lane $5,10^{-7}$; lane $6,10^{-8} ;$ lane $7,10^{-9}$.
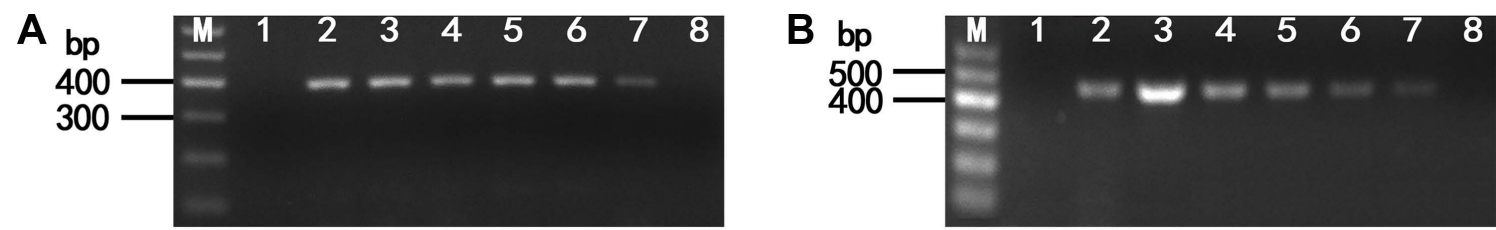

Fig. 6. Sensitivity of reverse transcription (RT) polymerase chain reaction (PCR) for (A) Lily mottle virus (LMoV) and (B) Arabis mosaic virus (ArMV). cDNA products were produced using total RNA extracted from lily leaves that were each infected with LMoV or ArMV, which were respectively diluted 10-fold and assayed by PCR. Amplified products from RT-PCR were visualized by agarose gel electrophoresis. (A) LMoV. Lane M, DL600 marker; lane 1, negative control; lane 2, initial cDNA; lane 3, 10 $0^{-1}$; lane 4, 10 ${ }^{-3}$; lane 5, $10^{-5}$; lane $6,10^{-7}$; lane $7,10^{-8}$; lane $8,10^{-9}$. (B) ArMV. Lane M, DL600 marker; lane 1, negative control; lane 2, initial cDNA; lane 3, $10^{-1}$; lane $4,10^{-3}$; lane $5,10^{-4}$; lane $6,10^{-5}$; lane $7,10^{-6}$; lane $8,10^{-7}$.

lower).

Evaluation of RT-LAMP using field-collected samples. We analyzed 20 field samples using both RT-LAMP and RT-PCR. For the lily samples, 7 were determined to be positive for LMoV and 13 were negative (Fig. 7A, upper and middle). Using the same procedure (i.e., applying both RT-LAMP and RT-PCR), of the 20 samples tested only one oriental hybrid lily sample was determined to be positive for ArMV while the remaining 19 samples were found to be negative (Fig. 7B, upper and middle). We further determined that the sequence of the ArMV CP gene from this Lanzhou isolate had a $90.2 \%$ similarity with a known ArMV lily isolate recorded in GenBank (accession no. AB279741) (data not shown).

Products from both methods analyzed using the SYBR Green I fluorescence technique with agarose gel electrophoresis provided similar results with respect to the 20 LMoV and ArMV-infected field samples to those discussed above (Fig. 7A, lower and 7B, lower).

\section{Discussion}

$\mathrm{LMoV}$ is one of most common viruses to infect lilies worldwide. In the Lanzhou region, such virus infections have contributed to a deterioration in bulb quality and a yield reduction greater than $50 \%$, namely, from 23,000 to $11,000 \mathrm{~kg}$ per hectare (Zhang et al., 2018). Recently ArMV was detected in LMoV-infected plants in an oriental lily field in this region, there is concern that once ArMV establishes within a lily production area, and it may result in further economic losses to the lily industry.

Although different methods have been developed for LMoV and ArMV detection, many require technical expertise and specialized equipment (Kulshrestha et al., 2005; Niimi et al., 2003; Zhang et al., 2015b). In this study, we report on the successful development of a simple, sensitive and reliable method to detect $\mathrm{LMoV}$ and ArMV using the RT-LAMP method at temperatures validated between $65^{\circ} \mathrm{C}$ and $70^{\circ} \mathrm{C}$ and $60^{\circ} \mathrm{C}$ and $70^{\circ} \mathrm{C}$ for $\mathrm{LMoV}$ and ArMV, 

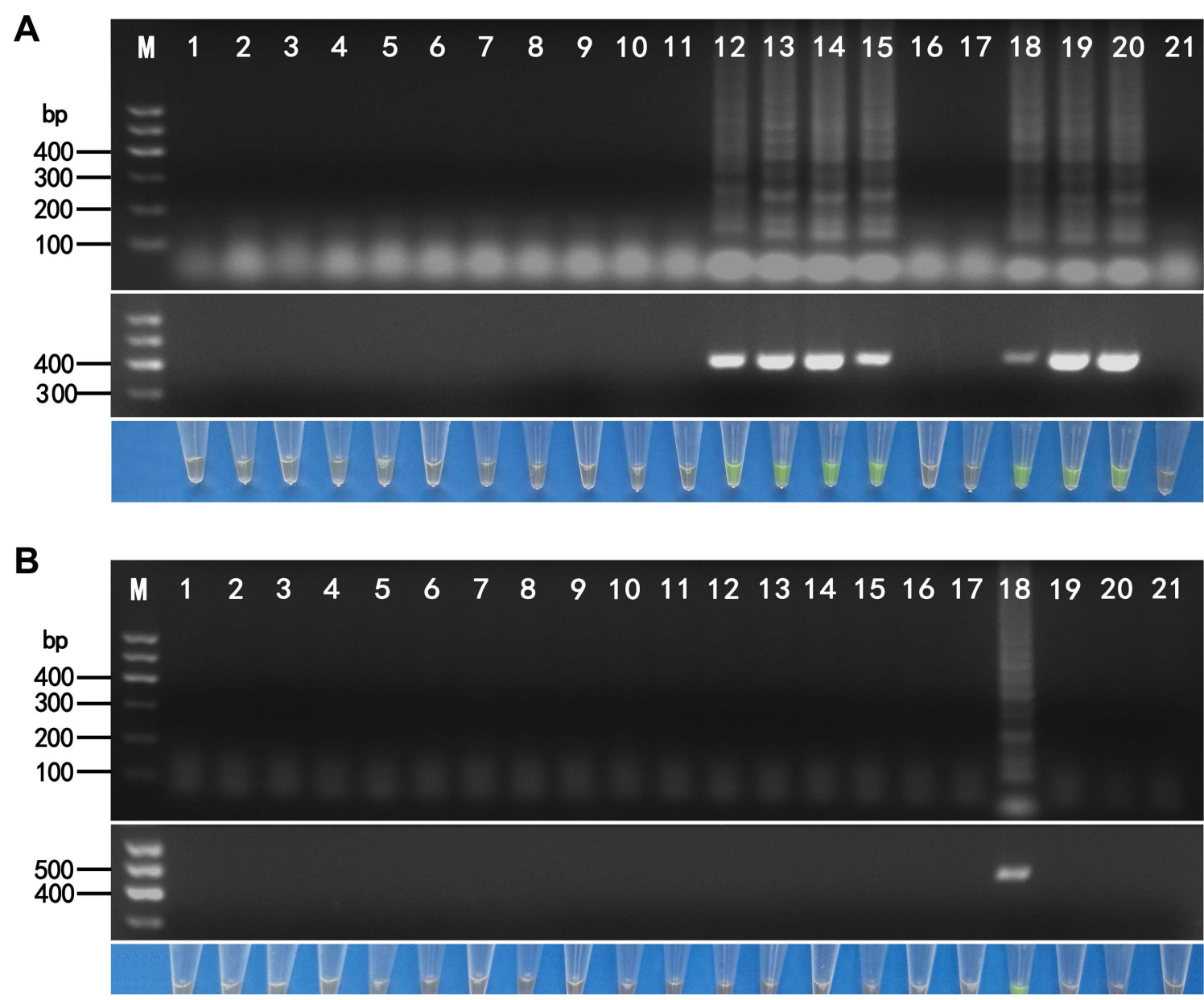

Fig. 7. Detection of Lily mottle virus (LMoV) (A) and Arabis mosaic virus (ArMV) (B) from field-collected lily samples by reverse transcription (RT) loop-mediated isothermal amplification (LAMP) and RT-polymerase chain reaction (PCR). Amplification products of RT-LAMP (upper) and RT-PCR (middle) were visualized by agarose gel electrophoresis, and by the naked eye with the addition SYBR Green I (lower). Lane M, DL600 marker; lane 1, negative control; lanes 2-11, Lanzhou lily (Lilium davidii var. unicolor) leaf samples; lanes 12-21, oriental hybrid lily (Lilium oriental cv. Sorbonne) leaf samples.

respectively, for approximately $60 \mathrm{~min}$. We found that both RT-LAMP and RT-PCR methods yielded similar results for field-collected samples. Moreover, using RT-LAMP, both detection limits were 100 times more sensitive than the RT-PCR method. These results further demonstrated that our RT-LAMP assay is a reliable method that is significantly more sensitive than RT-PCR.

Compared to the conventional RT-PCR method, RTLAMP is not only less expensive in relation to the equipment required but also more sensitive, and it has been used not only to detect plant viruses but also various other pathogens (Arita et al., 2009; Bühlmann et al., 2013; Kubota et al., 2008). In the development of an efficient LAMP amplification, the design, ratios and concentrations of LAMP primers are key factors in determining LAMP sensitivity (Hardinge et al., 2018). In this study, we found that differ- ent primer sets yielded different amplification in $\mathrm{LMoV}$ and ArMV detections (data not shown), and the optimum primer sets selected in this study could be a main reason for determining the high sensitivity performance of RT-LAMP assays. The optimization of the LAMP reaction temperature and duration (time) also played an important role in the successful detection of pathogens (Bhat et al., 2013). In determining the optimum temperature, the LAMP reaction was initially conducted using a thermal-cycler to maintain a constant temperature. Subsequently, two further options were assessed to ascertain their suitability for this purpose: a water bath and a heat block. We found that all three RTLAMP reaction incubation methods yielded similar amplification results (data not shown), which served to confirm that a device that can maintain a set temperature accurately is adequate for RT-LAMP amplification (Bhat et al., 2013). 
RT-LAMP products were routinely confirmed using agarose gel electrophoresis. As reported by several other studies (Bhat et al., 2013; Mengao et al., 2016; Ravindran et al., 2012), our experimental results also confirmed that RTLAMP products could be detected through a simple visual examination under green fluorescence using SYBR Green I. Both visual methods (gel electrophoresis and green fluorescence) yielded similar results with respect to specificity, detection limits and with field-collected samples (Figs. 4, 5, and 7). Our results also showed that visual indicators such as green fluorescence appear to be adequate for performing RT-LAMP in laboratories with minimal facilities. However, further research is required to develop a suitable rapid field-based RT-LAMP for lily crops using green fluorescence.

A previous study recently confirmed a low level of LMoV infection in the Lanzhou lily (Zhang et al., 2018). From our limited collection of field samples in this work, we neither detected LMoV nor ArMV in our Lanzhou lily samples using both RT-LAMP and RT-PCR methods. On the other hand, we did detect LMoV (70.0\%) and ArMV $(10.0 \%)$ in oriental hybrid lily samples using the same methods. While it is encouraging to note that $\mathrm{LMoV}$ and ArMV may not be well established in the Lanzhou lily in this region, further survey work needs to be undertaken to verify this conclusion. We plan to undertake further survey work in order to further clarify if either or both viruses are further establishing or spreading in Gansu Province. Based on this information monitoring and management programs of these two viruses should be strengthened in order to avoid the spread of disease and remove the threat of economic losses.

In conclusion, mixed infections of $\mathrm{LMoV}$ and ArMV show severe foliar symptoms, and likely bring about damage to the lily crop. Accordingly, we have developed a convenient, specific and sensitive RT-LAMP procedure for the detection of LMoV and ArMV. Through testing, we determined that this relatively simple technique should be more widely available for application owing to its low cost and minimal equipment requirements.

\section{Acknowledgments}

This study was supported by the Chinese Academy of Sciences (CAS) Key Technology Talent Program (Grant No. 2016-65), the Lanzhou Talent Innovation and Entrepreneurship Project (Grant No. 2019-09), the Lanzhou Chengguan District Science and Technology Project (Grant No. 2019-6-2), the Science and Technology Service Network Initiative of CAS (KFJ-STS-QYZD-120), the
Gansu Province Major Project of Science and Technology (Grant No. 18ZD2NA010), and the NTKJ2018-11. We would like to thank Mr. John D. Fletcher and Dr. H. R. Kutcher for reviewing our manuscript. The authors have no conflict of interest to declare.

\section{References}

Adams, A. N., Barbara, D. J. and Da Vies, D. L. 1987. The etiology of hop chlorotic disease. Ann. Appl. Biol. 111:365-371.

Arita, M., Ling, H., Yan, D., Nishimura1, Y., Yoshida, H., Wakita, T. and Shimizu, H. 2009. Development of a reverse transcription-loop-mediated isothermal amplification (RT-LAMP) system for a highly sensitive detection of enterovirus in the stool samples of acute flaccid paralysis cases. BMC Infect. Dis. 9:208.

Asjes, C. J. 2000. Control of aphid-borne Lily symptomless virus and Lily mottle virus in Lilium in the Netherlands. Virus Res. 71:23-32.

Bhat, A. I., Siljo, A. and Deeshma, K. P. 2013. Rapid detection of Piper yellow mottle virus and Cucumber mosaic virus infecting black pepper (Piper nigrum) by loop-mediated isothermal amplification (LAMP). J. Virol. Methods 193:190-196.

Brunt, A. A., Crabtree, K., Dallwitz, M. J., Gibbs, A. J. and Watson, L. 1996. Viruses of plants. CAB International, Wallingford, UK. 1484 pp.

Bühlmann, A., Pothier, J. F., Rezzonico, F., Smits, T. H. M., Andreou, M., Boonham, N., Duffy, B. and Frey, J. E. 2013. Erwinia amylovora loop-mediated isothermal amplification (LAMP) assay for rapid pathogen detection and on-site diagnosis of fire blight. J. Microbiol. Methods 92:332-339.

Derks, A. F. L. M., Lemmers, M. E. C. and van Gemen, B. A. 1994. Lily mottle virus in lilies: characterization, strains and its differentiation from tulip breaking virus in tulips. Acta Hortic. 377:281-288.

EFSA Panel on Plant Health. 2013. Scientific opinion on the risk to plant health posed by Arabis mosaic virus, Raspberry ringspot virus, Strawberry latent ringspot virus and Tomato black ring virus to the EU territory with the identification and evaluation of risk reduction options. EFSA J. 11:3377.

Gambley, C. F., Geering, A. D. W. and Thomas, J. E. 2009. Development of an immunomagnetic capture-reverse transcriptase-PCR assay for three pineapple ampeloviruses. $J$. Virol. Methods 155:187-192.

Hardinge, P., Kiddle, G., Tisi, L. and Murray, J. A. H. 2018. Optimised LAMP allows single copy detection of 35Sp and NOSt in transgenic maize using bioluminescent assay in real time (BART). Sci. Rep. 8:17590.

He, X., Xue, F., Xu, S. and Wang, W. 2016. Rapid and sensitive detection of Lily symptomless virus by reverse transcription loop-mediated isothermal amplification. J. Virol. Methods 238:38-41.

Keizerweerd, A. T., Chandra, A. and Grisham, M. P. 2015. Development of a reverse transcription loop-mediated 
isothermal amplification (RT-LAMP) assay for the detection of Sugarcane mosaic virus and Sorghum mosaic virus in sugarcane. J. Virol. Methods 212:23-29.

Kubota, R., Vine, B. G., Alvarez, A. M. and Jemkins, D. M. 2008. Detection of Ralstonia solanacearum by loop-mediated isothermal amplification. Phytopathology 98:1045-1051.

Kulshrestha, S., Hallan, V., Raikhy, G., Adekunle, O. K., Verma, N., Haq, Q. M. R. and Zaidi, A. A. 2005. Reverse transcription polymerase chain reaction-based detection of Arabis mosaic virus and Strawberry latent ringspot virus in vector nematodes. Curr. Sci. 89:1759-1762.

Kwon, J. Y., Ryu, K. H. and Choi, S. H. 2013. Reverse transcription polymerase chain reaction-based system for simultaneous detection of multiple lily-infecting viruses. Plant Pathol. J. 29:338-343.

Mengao, J., Yushuaang, G. and Fanjiang, X. 2016. Rapid detection of virus based on immunocapture combined with reverse transcription loop-mediated isothermal amplification. Tob. Sci Technol. 49:9-16.

Niimi, Y., Han, D. S., Mori, S. and Kobayashi, H. 2003. Detection of Cucumber mosaic virus, Lily symptomless virus and Lily mottle virus in Lilium species by RT-PCR technique. Sci. Hortic. 97:57-63.

Parida, M., Sannarangaiah, S., Dash, P. K., Rao, P. V. L. and Morita, K. 2008. Loop mediated isothermal amplification (LAMP): a new generation of innovative gene amplification technique; Perspectives in clinical diagnosis of infectious diseases. Rev. Med. Virol. 18:407-421.

Ravindran, A., Levy, J., Pierson, E. and Gross, D. C. 2012. Development of a loop-mediated isothermal amplification procedure as a sensitive and rapid method for detection of 'Candidatus Liberibacter solanacearum' in potatoes and psyllids. Phytopathology 102:899-907.

Sharma, A., Mahinghara, B. K., Singh, A. K., Kulshrestha, S., Raikhy, G., Singh, L., Verma, N., Hallan, V., Ram, R. and Zaidi, A. A. 2005. Identification, detection and frequency of lily viruses in northern India. Sci. Hortic. 106:213-227.

Viswanathan, R., Ganesh Kumar, V., Karuppaiah, R., Scindiya, M. and Chinnaraja, C. 2013. Development of duplex-immuno- capture (Duplex-IC) RT-PCR for the detection of Sugarcane streak mosaic virus and Sugarcane mosaic virus in sugarcane. Sugar Tech 15:399-405.

Wang, R., Wang, G., Zhao, Q., Zhu, Y., Zhan, J., Xie, Z., An, L. and Wang, Y. 2010. Molecular and cytopathologic evidences for a mixed infection of multiple viruses on Lanzhou lily (Lilium davidii var. unicolor) in northwestern China. J. Plant Dis. Prot. 117:145-149.

Zhang, Y., Wang, Y., Meng, J., Xie, Z., Wang, R., Kutcher, H. R. and Guo, Z. 2015a. Development of an immunochrographic strip test for rapid detection of Lily symptomless virus. $J$. Virol. Methods 220:13-17.

Zhang, Y., Wang, Y., Xie, Z., Yang, G., Guo, Z. and Wang, L. 2017. Simultaneous detection of three lily viruses using Triplex IC-RT-PCR. J. Virol. Methods 249:69-75.

Zhang, Y., Wang, Y., Xie, Z., Yang, G., Guo, Z. and Wang, L. 2018. The occurrence and distribution of viruses infecting Lanzhou lily in northwest, China. Crop Prot. 110:73-76.

Zhang, Y., Wang, Y., Yang, W., Xie, Z., Wang, R., Kutcher, H. R. and Guo, Z. 2015b. A rapid immunochromatographic test to detect the Lily mottle virus. J. Virol. Methods 220:43-48.

Zhao, B., Yang, D., Zhang, Y., Xu, Y., Zhao, X., Liang, J., Fan, X., Du, Y., Zhu, Z., Shi, B., Zhang, Q., Zhang, X., Cai, Y. and Zhao, K. 2018. Rapid visual detection of Lily mottle virus using a loop-mediated isothermal amplification method. Arch. Virol. 163:545-548.

Zhao, K., Liu, Y. and Wang, X. 2010. Reverse transcription loopmediated isothermal amplification of DNA for detection of Barley yellow dwarf viruses in China. J. Virol. Methods 169:211-214.

Zhao, L., Hao, X., Liu, H., Wang, Q. and Wu, Y. 2014. Rapid detection of Turnip mosaic virus by reverse transcription loop-mediated isothermal amplification. J. Phytopathol. 162:693-696.

Zheng, Y., Zhang, W., Lu, X., Zhang, G., Wang, H., Zhang, X., Feng, J. and Long, H. 2013. Specific and rapid detection of Lily symptomless virus and Arabis mosaic virus in lily by dual IC-RT-PCR. J. Phytopathol. 161:823-827. 